International Journal of Linguistics and Translation Studies

Volume 3, Issue 1, 2022

Homepage: http://ijlts.org/index.php/ijlts/index

DOI: $\underline{\text { https://doi.org/10.36892/ijlts.v3i1.209 }}$

\title{
Attitudes of Medical Sciences' Students towards English Language Learning: A Case Study of Health Sciences Colleges in Saudi Arabia
}

\author{
Mahdi Aben Ahmed \\ Jubail English Language and Preparatory Year Institute, Education Sector, Royal \\ Commission in Jubail \\ Mha1121@hotmail.com
}

\section{ARTICLE HISTORY}

Received: 05/01/2022

Accepted: 15/02/2022

\section{KEYWORDS}

Attitudes, behavioural component, affective component, cognitive component, language acquisition, English for Specific Purposes, and TESOL.

\section{Abstract}

Learning a new language is a challenging task for many learners. However, it can be an exciting learning process based on several individual difference factors such as self-esteem, anxiety, tolerance of ambiguity, motivation, and attitudes. Thus, this paper focused at examining the attitudes of private college students in Saudi Arabia towards learning the English language for medical academic purposes as it highlights the differences between male and female learners' attitudes towards learning English language. Relevant data was attained by employing survey questionnaires from a sample of 200 students selected from three private medical colleges that utilize the English language as a medium of instruction in Saudi Arabia. SPSS analysed the accumulated data. The findings dominantly revealed that students have positive attitudes toward learning the English language, especially if the materials are authentic and related to their respective medical areas of concentration and related to their future workplace. Moreover, the study disclosed that there was no significant difference in the learners' attitudes toward English language learning based on gender. This study's findings are highly recommended to EFL students, teachers, policymakers, and researchers who are interested in investigating linguistic-associated behaviours. The findings can additionally reinforce related studies or serve as framework for further research studies of the same nature.

\section{INTRODUCTION}

Over the years, the English Language has transformed as a crucial means of communication globally among native and non-native speakers, and it has become the language of international and intercultural communication (AlTameemy \& Alrefaee, 2021; Al-Ghamdi, Almansoob \& Alrefaee, 2019). Given the lingua franca status of English, it is clear that people all over the world need and use English for professional and technical reasons such as professional contacts and academic studies.

Countries around the world possess increasing awareness in integrating English instructions in their curricula. Some educational institutions around the world prescribed English language as the major medium of instruction in their universities to prepare their students with skills needed for success in their fields of specializations and future professions. This was the main reason for the innovation and increasing significance of English for Specific Purposes (ESP) as a vital sub-field of Teaching English to Speakers of Other Languages 
(TESOL). In ESP, it is well known that non-native speakers of English do not learn English for the purpose of general English education, but to use it in their academic or professional environments.

To be able to effectively implement English courses as ESP for a specific major and achieve the desired outcomes, several affective factors such as attitudes and motivation play a significant role in enhancing or hurting foreign language learning in general, and ESP in specific. Researchers believe that high motivation and positive attitude towards a foreign language and its people support foreign language learning (Dornyei, 2001; Saville-Troike, 2006). Second language scholars regularly declare that learners with higher motivation and a positive attitude learn another language faster and with a higher level of proficiency (Brown, 2000; Yule, 2010).

It is thought that positive characteristics and traits contribute to language learning; learners need those traits to realize the anticipated consequence and win overcome any language learning barriers. Dornyei (2005) contended that there are several influences that hinder learners' acquisition of foreign language and these comprise attitude, motivation, selfconfidence, and beliefs. Snow (2007) supported that the attitude of learners serves as an indicator that stimulates the policy of teaching a certain language. This leads language scholars to emphasize that attitude is a major factor for the acquisition of a second language. Consequently, the possibility of acquiring and learning a second language is high when learners develop or have good attitude toward the language they are studying (Savignon, 1997). Thus, learners who have a negative attitude toward learning a language usually find it hard to acquire the language they are learning as compared to those who possess a positive attitude. Likewise, aside from language skills and mental ability being factors that impede the achievement of a second language, the attitude of the learner also plays a key role in the language learning process (Gardner and Lambert, 1972). These authors discovered that the influence of the attitude could be a consequence of students' beliefs towards the target language and these are going to be manifested in the language learning process.

In addition, learners are motivated by their constructive attitudes, indirectly linking with the process of learning a new language. Hence, instilling a positive attitude in them to motivate or elevate their passion for learning languages is necessary (Tahaineh and Danna, 2013). Dörnyei and Csizér (2002) disclosed that negative attitude in learners fails to enable learning motivation while favourable attitude ignites, polishes, and enhances the foreign language acquisition.

As perceived generally, there is varied range of attitudes from positive, neutral, and negative which affect the process of learning a foreign language. They differently influence the efficacy of learning new languages. Practically, the development of a positive or negative attitude determines the difficulty levels of how language is learned. Moreover, various investigations have been conducted to determine the impacts of learning a second language based on gender and based on specific groups of learners based on the areas that they learn. However, the results of these inquiries are still inconsistent (Aydin, 2007).

This study sought answers to the following specific questions:

1. What are the classified observed attitudes of medical science students on English language learning?

2. What pedagogical significance do medical science students' attitudes offer in language acquisition?

3. How do these attitudes significantly contribute towards EFL students, teachers, policymakers, and researchers? 


\section{LITERATURE REVIEW}

It is interesting to note that there are numerous studies conducted by language scholars that embrace the field of language acquisition originating from different times and places which may support this study. Some of this indirectly refer to this paper's discoveries.

Attitude is perceived to play a main role in any learning process. This is most specifically observed when learning foreign languages. Compared to other factors, attitude has been the key area of concern for various social psychologists because investigating the learners' attitude helps in directing social behaviour (Gardner, 1985). Researchers have come up with several definitions for attitudes. According to Allport (1967), attitude is a state of readiness of the mind which is structured through knowledge and applying a directive impact in the response of an individual to all situations that are linked to.

Additionally, Oppenheim (1992) showed that attitude involves a mindset of readiness, the ability to act or react in a certain way when challenged by a particular environmental change. The response is mostly exhibited in form of behavior when exposed to a certain change in environment. Besides, Ajzen (1988) viewed attitude as the character of responding either positively or negatively to a person or event. Ahmed (1989) claimed that attitude encompasses sets of believes that cause an individual to respond in a particular manner as a result of the change. Similarly, Baker (1992) maintained that attitude is a theoretical development that explains the way and human behavior persistence. Spolsky (2000) argued that the attitudes of learners are revealed through their fear of learning, and motivation of learning a foreign language. Thus, Gardner (1985) also argued that the degree of success of students in obtaining a second language is directly proportional to the attitude they have towards the language to be learned. In other words, learners with a negative attitude find it hard to learn easily during the learning of a second language process while students with a positive attitude learn the language smoothly. In other words, a positive attitude accelerates the second language learning process.

Gardner (1985) contended that the belief of learners controls the evaluative response towards objects, individuals, or circumstances. Hence that the attitude structure reflects the feelings and beliefs of the learners. Triandis (1971) pointed out that attitude can be grouped into three major categories which include cognitive component, behavioral component, and affective component. Consequently, Triandis (1971) explained that the cognitive component talks about the beliefs that an individual possesses towards a social object or situation. The development of the beliefs could be structured in accordance with thoughts that are not real, but people having this attitude usually believes it is real. These beliefs vary from one person to another according to the experience a learner develops in a certain state. Also, the affective component encompasses the feelings that learners develop in the learning of the desired language or the favorable language. Besides, the behavioral component involves the features of the learner's readiness for acting on a certain object or circumstance. It can be demonstrated in two different ways. First, it can be revealed explicitly in day-to-day learner behavior or it can be exhibited implicitly on the way a learner expresses himself during communication. This element of attitude enables us to understand the perception of learners on learning a particular language.

Attitude has been identified from numerous characteristics and ideas an individual possesses. Basically, the value of attitudes varies from one individual to another. The strength and the value illustrate the level of gladness that the learner possesses which can be either be sturdy or frail towards something. The second is that attitudes consist of instructional steps that represent varied stages of favourable and unfavourable evaluation or the acceptance or 
rejection to the object where the attitude is being observed. Furthermore, the attitude has some stages of privacy. Typically, they are classified into two kinds which are public and private attitudes. Private attitude is when learners attempt not to reveal his attitudes. In contrast, public attitude is observed when the learner continuously reveals his attitude and particularly to those whom he shares common interests with (Al-Hoorie, 2016a, 2016b). Moreover, attitude can be diffused from one person to another or from a context to another synchronizing to one's behavioural inclination. Lastly, attitude has the probability to transform over time as a result of the differences in the adjoining setting where one is exposed to(Oxford, 1994; Gardner, 1985).

Several studies have examined the EFL learners' attitudes toward learning a second or foreign language. Gence and Aydin (2017) found a weak correlation between the students' attitudes and motivation with regard to academic achievements (see also Al-Hoorie, 2018). They also found no relationship between the student's area of study and their motivation in English language learning. Dehbozorgi (2012) examined the impact of learners' attitudes on learning English and also risk-taking on their English proficiency. The results revealed that no association existed between the students' attitude and their degree of proficiency. Moreover, the students reported that they had a positive attitude in learning an unfamiliar language; this does not automatically guarantee that they possess a high proficiency level.

In contrast, Tahaineh and Daana (2013) conducted a study in Jordon intended to assess the attitude of learners and motivation toward learning the English language. They revealed that the undergraduate learners had a positive attitude towards studying English and this enables them to acquire the language within a short duration of time. Moreover, Al-Samadani and Ibnain (2015) investigated the attitude of undergraduates concerning studying a foreign language and also the association between their academic attainment and attitudes in Saudi Arabia universities. It was evident that the learners had a very high positive attitude concerning studying a foreign language. Moreover, the findings indicated that there was a direct relationship between the level of students' achievements and their attitude. In short, students with a positive attitude towards English learning scored higher grades in their exams. Besides, Latif et al (2011), in their study in Malaysia, revealed that the learners with positive attitudes had higher scores compared to others with negative attitudes. A positive association is confirmed among instrumental orientation, personal motivation, and attitude towards English learning in association with the performance of students in the English language.

\section{METHOD}

The study employed the quantitative approach in the selection and analysis of the gathered data of this investigation. This method was beneficial towards the achievement of this study's objectives.

\subsection{Participants}

The study participants encompassed 200 learners: 100 male and 100 female. The participants were chosen randomly from three private medical sciences colleges in Saudi Arabia. The researcher selected the participants based on their proximity for easy access and data collection and also based on the unique features of learners. The colleges that were selected offered different health sciences-related majors. The researcher believes that the findings of the current study might be generalized to other students in the country.

\subsection{Data collection instrument}

The research employed a survey to gather data from the participants regarding their attitudes towards learning English language. The questionnaire was developed and supported 
by confirmation of the items through a pool of several psych-educational experts to ensure the instruments' validity and reliability.

\subsection{Validity and reliability of the data collection instrument}

Cronbach's Alpha was calculated using SPSS for purposes of determining the extent to which the data collection instrument was reliable. In Table 1, the calculated index of Cronbach's alpha reliability for the questionnaire was .84 , conforming to the required level required by Howitt and Cramer (2005) where the Cronbach's Alpha to be higher than .70 so that the questionnaire is valid for use.

Table (1) reliability statistics

\begin{tabular}{|l|l|}
\hline Cronbach's Alpha & No of Items \\
\hline .84 & 24 \\
\hline
\end{tabular}

\subsection{Demographic Profille of Sample}

The total sample of the study was made up of two hundred undergraduate students. They were selected randomly from different medical colleges in Saudi Arabia. Table 2 shows the demographic distribution among colleges and gender.

Table (2) the distribution of participants

\begin{tabular}{|c|c|c|c|c|}
\hline $\mathbf{N}$ & College & $\begin{array}{c}\text { Participants } \\
\text { (total) }\end{array}$ & Male & Female \\
\hline $\boldsymbol{1}$ & College of Pharmacy & 80 & 40 & 40 \\
\hline $\mathbf{2}$ & College of Nursing & 60 & 30 & 30 \\
\hline $\mathbf{3}$ & $\begin{array}{c}\text { College of Health } \\
\text { Sciences }\end{array}$ & 60 & 30 & 30 \\
\hline
\end{tabular}

\section{Data analysis}

Quantitative data were analysed by the constant comparative technique. It involved data assembling, comparing data, interpreting data, and reporting the results. The data was displayed in form of percentages and frequencies based on the attitudes of learners to studying the English language. The data obtained from the questionnaires were analysed and tested by SPSS statistic software.

\section{FINDINGS}

Table 3: Attitudes of Learners of Saudi Arabia toward Learning English.

\begin{tabular}{|l|l|l|l|l|l|l|}
\hline & Item & Highly & Agree & Neutral & Disagree & $\%$ \\
\hline $\mathbf{1}$ & $\begin{array}{l}\text { I like to practice English the way native } \\
\text { speakers do }\end{array}$ & 70 & 20 & 5 & 5 & $\mathbf{1 0 0}$ \\
\hline $\mathbf{2}$ & $\begin{array}{l}\text { Studying English helps me to have good } \\
\text { associations with } \\
\text { friends }\end{array}$ & 55 & 30 & 10 & 5 & $\mathbf{1 0 0}$ \\
$\mathbf{3}$ & $\begin{array}{l}\text { When I hear a learner in-class speaking } \\
\text { English perfectly, I like to practice } \\
\text { speaking with him/her }\end{array}$ & 60 & 30 & 0 & 10 & $\mathbf{1 0 0}$ \\
\hline $\mathbf{4}$ & $\begin{array}{l}\text { learning English is important for my } \\
\text { personal and academic development }\end{array}$ & 75 & 25 & 0 & 0 & $\mathbf{1 0 0}$ \\
\hline $\mathbf{5}$ & $\begin{array}{l}\text { I feel worried about Speaking English } \\
\text { anywhere }\end{array}$ & 30 & 15 & 0 & 55 & $\mathbf{1 0 0}$ \\
\hline
\end{tabular}




\begin{tabular}{|c|c|c|c|c|c|c|}
\hline 6 & $\begin{array}{l}\text { I put off my English homework as much } \\
\text { as possible }\end{array}$ & 10 & 20 & 5 & 65 & 100 \\
\hline 7 & $\begin{array}{l}\text { Whenever I have to speak English in my } \\
\text { class, I am not usually relaxed }\end{array}$ & 25 & 15 & 0 & 60 & \\
\hline 8 & $\begin{array}{l}\text { I feel embarrassed to speak English in } \\
\text { front of other students }\end{array}$ & 10 & 25 & 5 & 60 & 100 \\
\hline 9 & $\begin{array}{l}\text { I never ask my friends or teachers for } \\
\text { the homework on what has been taught } \\
\text { when I miss the class }\end{array}$ & 5 & 5 & 15 & 75 & 100 \\
\hline 10 & $\begin{array}{l}\text { I do not feel enthusiastic to come to class } \\
\text { when the English are } \\
\text { being thought }\end{array}$ & 10 & 15 & 5 & 70 & 100 \\
\hline
\end{tabular}

The results, in Table 3, revealed that the majority of the learners (70\%) highly agreed that they love to practice English just as native speakers do. Similarly, the majority of the learners (55\%) reported that learning English helps them to relate well with their colleagues. Additionally, a slightly large percentage of the students (60\%) stated that when they hear a learner in their class speaking English perfectly, they like to practice speaking with them. For personal development and high academic achievements, most of the learners (75\%) highly agreed that English helps them in their personal and academic life. Most students (55\%) disagreed with the fact that speaking English anywhere makes them feel worried. Similarly, a total of $(65 \%)$ of the students disagreed with the fact that they put off their English homework as much as possible. Based on relaxing whenever they speak in class, a large percentage of learners $(60 \%)$ disagreed with this idea. Moreover, a significantly larger portion of students $(60 \%)$ claimed that they disagree with the fact that they feel embarrassed speaking English in front of other learners. A total of (75\%) of the learners disagreed with the idea that when they miss a lesson, they never ask their colleagues or instructors for the homework on what they learned in class. Likewise, a large percentage of the learners (70\%) disagreed that they do not feel enthusiastic coming to class during the English lesson. The findings depict that students had positive attitudes concerning learning English.

Table 4: Difference among male and female learners with regard to their attitudes to learning the English language

\begin{tabular}{|c|c|c|c|c|c|c|}
\hline No. & Variable & Gender & $\begin{array}{l}\text { Highly } \\
\text { agree }\end{array}$ & Agree & Neutral & Disagree \\
\hline 1 & $\begin{array}{l}\text { Learning foreign languages like } \\
\text { English is enjoyable }\end{array}$ & $\begin{array}{l}\text { Male } \\
\text { female }\end{array}$ & $\begin{array}{l}70 \\
75\end{array}$ & $\begin{array}{l}15 \\
10\end{array}$ & $\begin{array}{l}5 \\
10\end{array}$ & $\begin{array}{l}10 \\
5\end{array}$ \\
\hline 2 & $\begin{array}{l}\text { when studying the English } \\
\text { language, I feel proud }\end{array}$ & $\begin{array}{l}\text { Male } \\
\text { Female }\end{array}$ & $\begin{array}{l}65 \\
78\end{array}$ & $\begin{array}{l}30 \\
15\end{array}$ & $\begin{array}{l}3 \\
2\end{array}$ & $\begin{array}{l}2 \\
5\end{array}$ \\
\hline 3 & $\begin{array}{l}\text { Studying English makes me feel } \\
\text { more confident }\end{array}$ & $\begin{array}{l}\text { Male } \\
\text { Female }\end{array}$ & $\begin{array}{l}55 \\
64\end{array}$ & $\begin{array}{l}26 \\
19 \\
\end{array}$ & $\begin{array}{l}10 \\
12\end{array}$ & $\begin{array}{l}9 \\
5\end{array}$ \\
\hline 4 & $\begin{array}{l}\text { I have an interest in learning the } \\
\text { English language for my medical } \\
\text { major }\end{array}$ & $\begin{array}{l}\text { Male } \\
\text { Female }\end{array}$ & $\begin{array}{l}80 \\
83\end{array}$ & $\begin{array}{l}10 \\
8\end{array}$ & $\begin{array}{l}0 \\
0\end{array}$ & $\begin{array}{l}10 \\
9\end{array}$ \\
\hline 5 & $\begin{array}{l}\text { Understanding English is a } \\
\text { crucial goal in my life }\end{array}$ & $\begin{array}{l}\text { Male } \\
\text { Female }\end{array}$ & $\begin{array}{l}73 \\
77\end{array}$ & $\begin{array}{l}15 \\
12\end{array}$ & $\begin{array}{l}5 \\
3\end{array}$ & $\begin{array}{l}7 \\
8\end{array}$ \\
\hline 6 & $\begin{array}{l}\text { Learning English makes me } \\
\text { develop good emotions }\end{array}$ & $\begin{array}{l}\text { Male } \\
\text { Female } \\
\end{array}$ & $\begin{array}{l}60 \\
58\end{array}$ & $\begin{array}{l}33 \\
39 \\
\end{array}$ & $\begin{array}{l}4 \\
3\end{array}$ & $\begin{array}{l}3 \\
0\end{array}$ \\
\hline 7 & $\begin{array}{l}\text { Honestly speaking, I do have } \\
\text { little interest in my English } \\
\text { classes }\end{array}$ & $\begin{array}{l}\text { Male } \\
\text { Female }\end{array}$ & $\begin{array}{l}5 \\
4\end{array}$ & $\begin{array}{l}15 \\
12\end{array}$ & $\begin{array}{l}21 \\
18\end{array}$ & $\begin{array}{l}59 \\
66\end{array}$ \\
\hline
\end{tabular}


Table (4) shows that a large percentage of both males and females $(70 \%, 75 \%)$ highly agreed that learning foreign languages such as English is enjoyable. Similarly, most of the males and females $(65 \%, 78 \%)$ highly agreed that they feel proud when learning English. Additionally, $55 \%$ and $64 \%$ of both males and females respectively claimed that they felt more confident studying English subjects. Based on interest in studying English, a very large percentage of males and females $(80 \%, 83 \%)$ claimed that they are interested in studying English. Most males and females $(73 \%, 77 \%)$ claimed that understanding English is a crucial goal in their life. Similarly, a large percentage of males and females $(60 \%, 58 \%)$ highly agreed that they developed good emotions while studying English. However, a slightly larger percentage of males and females $(59 \%, 66 \%)$ respectively disagreed with the fact that they really have little interest in their English class. The findings indicate that there is no much difference between males and females based on their attitude in learning English.

Table 5: Learners' Negative and Positive Cognitive Attitudes Concerning English learning

\begin{tabular}{|l|l|l|l|l|l|}
\hline No. & Variable & $\begin{array}{l}\text { Highly } \\
\text { agree }\end{array}$ & Agree & Neutral & Disagree \\
\hline $\mathbf{1}$ & $\begin{array}{l}\text { Doing well in English will make me pass } \\
\text { other medical subjects }\end{array}$ & 56 & 22 & 6 & 6 \\
\hline $\mathbf{2}$ & $\begin{array}{l}\text { I have more knowledge and } \\
\text { understanding when studying English }\end{array}$ & 53 & 34 & 5 & 8 \\
\hline $\mathbf{3}$ & $\begin{array}{l}\text { Learning English helps me to speak } \\
\text { perfectly in English }\end{array}$ & 72 & 21 & 3 & 4 \\
\hline $\mathbf{4}$ & $\begin{array}{l}\text { I create new thoughts when studying in } \\
\text { English }\end{array}$ & 64 & 18 & 10 & 8 \\
\hline $\mathbf{5}$ & $\begin{array}{l}\text { Honestly, I learn English just for the sake } \\
\text { of passing my exams }\end{array}$ & 9 & 13 & 19 & 59 \\
\hline $\mathbf{6}$ & $\begin{array}{l}\text { I cannot use the skills and knowledge I } \\
\text { obtain in English in the medical world }\end{array}$ & 12 & 9 & 15 & 64 \\
\hline $\mathbf{7}$ & $\begin{array}{l}\text { In my point of view, it is hard to learn the } \\
\text { English language }\end{array}$ & 20 & 18 & 5 & 57 \\
\hline
\end{tabular}

The study also aimed to identify the cognitive attitude of students towards learning English. Table (5) displays the results of the findings. A large percentage of the students $(56 \%)$ highly agreed that doing well in English will make them pass other subjects. Based on the idea of knowledge and understanding, a slightly larger percentage of the learners (53\%) highly agreed that they get more understanding and knowledge while studying in English. Similarly, most of the students (72\%) stated that studying English helps them to speak perfectly in English. The majority of the learners $(64 \%)$ highly agreed with the fact that studying English enables them to develop and create new thoughts. However, a larger percentage of the students (59\%) disagreed with the idea that they study English just for the sake of passing their exams. Similarly, (64\%) of the learners disagreed with the fact that they cannot apply the skills obtained from English in the real world and most of them (57\%) also disagreed that they find it hard to learn the English language. The above findings revealed that learners had a positive cognitive attitude towards English.

\section{DISCUSSION}

\subsection{Attitudes}

The key reason for conducting the current study is to identify the attitudes of learners in private medical colleges towards learning English for specific purposes as well as investigate if there are differences attributed to gender. Additionally, identify the cognitive attitudes of the medical colleges' students towards learning English. To this end, the study collected and examined data about the students' attitudes in three health sciences colleges in Saudi Arabia. 
The results revealed that learners had positive attitudes towards learning English in general, and to ESP in specific. Hence, the findings showed that students valued the English language. They did not just consider English as a subject to pass the exam but also they identified and appreciated the importance of English for their academic study in health, and for the medical workplace outside the classroom.

The results were supported by Al-Tamimi \& Shuib (2009) and Abu-Snoubar (2017). They stated that learners exhibited a positive attitude to studying English. According to Dörnyei and Csizér (2002), a positive attitude makes the process of learning English easier and interesting while a negative attitude acts as an obstacle towards learning English. However, these results contracted the findings of the studies conducted by Abidin et al, (2012), Shams (2008), ANofaie (2010), where they revealed that students had a negative outlook on learning English.

Therefore, attitudes can be grouped into three categories, namely, a positive attitude, negative attitude, and neutral attitude. All three categories are great determinants of whether the English learning process will be easier or not. This reveals the crucial role of having a positive attitude towards English. Simply, the attitude of an individual is the great determinant of learning English as a foreign language (Gardner \& Lambert, 1972).

The findings of the study also revealed that there was no significant difference between male and female learners towards learning English. This is because both males and females like to learn English and believe it is prestigious as well as vital to speak and use English in real life not just for school requirements. This result goes hand in hand with the works of (Karatas, 2016; Jabeen, 2011), who discovered that there is no such great difference between males and females in learning a second language. This indicates that both males and females strive very hard to overcome the barriers that hinder them to learn English effectively as both genders had a passion for learning English and they were driven by their values and beliefs.

Overall, pedagogically these findings imply that valuing or determining the future importance of the language that they learn contribute to easier language acquisition while unfavourable attitude towards a language being learned hamper the efficacy of the learning process. This study also establishes that gender does not divide male and female interests towards language learning. Both take every effort to acquire English to interact globally, enhance their chances in academic success, find better job, become effective communicators in the workplace, and to gain competitiveness in the increasingly globalized world.

\section{CONCLUSION}

The study aimed at identifying the extent to which attitudes influence the English learning process and also whether gender had an impact on English learning. From the findings of the study, it was evident that learners had a positive attitude concerning learning the English language, especially if is related to their field of academic study. Furthermore, there was no great difference in learning English based on gender. This shows that students were more aware of the importance of learning English especially for their major and professions. The results of the findings also indicated that there was no great difference in both genders' attitudes towards learning English. It is also noted that students at private medical college feel motivated and have positive attitude toward learning English. It is clear that they are encouraged to learn English, and do not feel forced to learn or use English. The relevance of ESP topics to students' major seem to affect students' attitudes positively as well.

\subsection{Recommendations}

With the mentioned significance of attitudes towards English language learning in this paper, these recommendations are hereby shared. First, to be able to fruitfully attain satisfactory 
awareness and skills of the English language being learned, it is required that students recognize and anticipate its real-life importance.

Classroom teachers should develop a good practice in setting-up a classroom atmosphere that inspires or conditions every learner to develop favourable attitudes towards the language to be learned such the implementation of appropriate strategies, instructional tools, and authentic materials used in the real medical workplace.Thus, some of the implication of this study are that the physical learning environment and situations should be improved, affective factors should be taken into consideration, and the specificity of ESP textbook selection and its relevance and practical use in medical classes and professions must be considered. All of these will have positive impact on students' attitude.

Policymakers from the education sectors should formulate and mandate guidelines on implementing "positive attitudes to learning" agenda in all schools nationwide where language curricula stipulate this and observe its practice. Finally, it is recommended that language researchers should be mindful of this papers' significant findings for this may underpin their research studies on language learning process.

\section{References}

Abidin, M. J. Z., Pour-Mohammadi, M., \& Alzwari, H. (2012). EFL students' attitudes towards learning English language: The case of Libyan Secondary School students. Asian Social Science, 8, 119-134.

Ahmed, H. A. (1989). The role of attitudes and motivation in teaching and learning Foreign languages: a theoretical and empirical investigation into the teaching and learning of English in Iraqi preparatory schools.

Ajzen, I. (1988). Attitudes, personality, and behaviour. Chicago: Dorsey Press.

Al Samadani, H.A. \& Ibnian, S.S. (2015). The Relationship between Saudi EFL Students 'Attitudes towards Learning English and their Academic Achievement. International Journal of Education and Social Science, 2 (1), 92-102.

Al-Ghamdi, N. A., Almansoob, N. T., \& Alrefaee, Y. (2019). Pragmatic failure in the realization of the speech act of responding to compliments among Yemeni EFL undergraduates. 3L: The Southeast Asian Journal of English Language Studies, 25 (4), $1-14$.

Al-Hoorie, A. H. (2016a). Unconscious motivation. Part II: Implicit attitudes and L2 achievement. Studies in Second Language Learning and Teaching, 6(4), 619-649.

Al-Hoorie, A. H. (2016b). Unconscious motivation. Part I: Implicit attitudes toward L2 speakers. Studies in Second Language Learning and Teaching, 6(3), 423-454.

Al-Hoorie, A. H. (2018). The L2 motivational self system: A meta-analysis. Studies in Second Language Learning and Teaching, 8(4), 721-754.

Allport, G. (1967). Attitudes. In M. Fishbein (Ed.), Readings in attitude theory and measurement (pp. 1-13). New York: John Wiley \& Sons.

Al-Nofaie, H. (2010). Attitudes of Teachers and Students towards Using Arabic in EFL Classrooms in Saudi Public Schools- A Case Study. Research on Youth and Language, 4(1), 64-95.

AlTameemy, F. A., Alrefaee, Y. (2021). Impact of Covid-19 on English Language Teaching in Yemen: Challenges and Opportunities. TESOL International Journal, 16 (4.4). 238252

Al-Tamimi, A. \& Shuib, M. (2009). Motivation and attitudes towards learning English: A study of petroleum engineering undergraduates at Hadhramout University of Sciences and Technology. GEMA Online Journal of Language Studies, 9(2), 29-55.

Aydin, E. (2007). An Analysis of Motivations, Attitudes, and Perceptions of the Students at TOBB University of Economics and Technology toward Learning English as a Foreign Language. Unpublished Master's Thesis, Hacettepe University, Ankara, Turkey. 
Baker, C. (1992). Attitudes and Language. Clevedon, England: Multilingual Matters.

Brown, H. D. (2000). Principles of language learning and teaching. White Plains, NY:

Pearson Education.

Dehbozorgi, E. (2012). Effects of attitude towards language learning and Risk-taking on EFL student's proficiency. International Journal of English Linguistics, 2(2), 41-48.

Dornyei, Z. (2001). New themes and approaches in second language motivation research. Annual Review of Applied Linguistics, 21, 43-59.

Dörnyei, Z. and Csizér, K. (2002). Some dynamics of language attitudes and motivation: Results of a longitudinal national survey. Applied Linguistics, 23, 421-462.

Dornyei, Z. \& Shoaib, A. (2005). Affect in lifelong learning: Exploring L2 motivation as a dynamic process. In Nunan, D. \& Benson, P. (Eds.) Learners' stories: Difference and diversity in language learning. (pp.22-41). Cambridge University Press: UK.

Gardner, R. \& Lambert, W. (1972). Attitudes and motivation in second language learning. Rowley, MA: Newbury House.

Genc, Z. S., \& Aydin, F. (2017). An Analysis of Learners' Motivation and Attitudes toward Learning English Language at Tertiary Level in Turkish EFL Context. English Language Teaching, 10(4), 35-44.

Howitt, D., \& Cramer, D. (2005). Introduction to SPSS in Psychology: with supplements for releases $10,11,12$ and 13 . Pearson education.

Jabeen, F., \& Shah, S. K. (2011). The role of culture in ELT: Learners' attitude towards the teaching of target language culture. European Journal of Social Sciences, 23(4), 604613.

Karatas, H., Alci, B., Bademcioglu, M., \& Ergin, A. (2016). Examining university students' attitudes towards learning English using different variables. International Journal of Educational Researchers, 7(3), 12-20.

Latif, L. A., Fadzil, M., Bahroom, R., Mohammad, W., \& San, N. M. (2011). The role of motivation, attitude, anxiety and instrumental orientation in influencing learners' performance in English as a second language in OUM. Global Conference on Learning and Technology. Melbourne, Australia: Global learn Asia Pacific. Retrieved from http://eprints.oum.edu.my/56.

Oppenheim, A. N. (1992). Questionnaire design, interviewing and attitude measurement (2Rev.ed.). London: Pinter Publishers.

Oxford, R. \& J. Shearin, (1994). Language Learning Motivation: Expanding the Theoretical Framework. Modern Language Journal, 78 (1), 12 - 28.

Savignon, J. (1997). Communicative competence, theory and classroom practice: Texts and contexts in second language learning (2nd Ed.). New York: McGraw-Hill.

Saville-Troike, M. (2006). Introducing second language acquisition. New York, NY: Cambridge University Press.

Shams, M. (2008). Students' attitudes, motivation and anxiety towards English language learning. Journal of Research, 2(2), 121-144.

Snow, D. (2007). Sustaining self-directed language learning in the Chinese context. English language teaching in China: New approaches, perspectives and standards, 211-232.

Spolsky, B. (2000). Language motivation revisited: Anniversary article. Applied Linguistics, 20(2), 157 169. http://dx.doi.org/10.1093/applin/21.2.157.

Tahaineh, Y. and Daana, H. (2013). Jordanian Undergraduates' Motivations and Attitudes towards Learning English in EFL Context, International Review of Social Sciences and Humanities Vol. 4, No. 2, pp. 159- 180.

Triandis, H. C. (1971). Attitude and Attitude Change (Foundations of Social Psychology). New Jersey: John Wileys \& Sons Inc.

Yule, G. (2010). The study of language. Cambridge, UK: Cambridge University Press. 